\title{
Strain localisation within ductile shear zones beneath active faults: The Alpine Fault contrasted with the adjacent Otago fault system, New Zealand
}

\author{
Richard J. Norris \\ Department of Geology, University of Otago, PO Box 56, Dunedin, New Zealand
}

(Received April 29, 2004; Revised October 18, 2004; Accepted November 25, 2004)

\begin{abstract}
The Alpine Fault accommodates around $60-70 \%$ of the $37 \mathrm{~mm} / \mathrm{yr}$ oblique motion between the Australian and Pacific plates in the South Island of New Zealand. Uplift on the fault over the past $5 \mathrm{Ma}$ has led to the exhumation of the deep-seated mylonite zone alongside the present surface trace. Shear strain estimates in the mylonites reach 200-300 in the most highly strained rocks, and provide an integrated displacement across the zone of 60-120 km. This is consistent with the amount of displacement during the last $5 \mathrm{Ma}$, suggesting that displacement on the fault is localised within a 1-2 km wide ductile shear zone to depths of 25-30 km. Existing geodetic data, together with Late Quaternary slip rate and paleoseismic data, are consistent with the steady build-up and release of elastic strain in the upper crust driven by ductile creep within a narrow mylonite zone at depth. Faults of the Otago Fault System form a parallel array east of the Alpine Fault and accommodate c. $2 \mathrm{~mm} / \mathrm{yr}$ contraction. Long periods of quiescence on individual structures suggest episodic, or "intermittently characteristic", behaviour. This is more consistent with failure on faults within an elastico-frictional upper crust above a ductile lower crust. Localisation of crustal deformation may be initiated by inherited weaknesses in the upper crust, with downward propagation of slip causing strain weakening within the ductile zone immediately beneath. Inherited structures of great length focus a greater amount of displacement and hence more rapidly develop underlying zones of ductile shear.
\end{abstract}

Key words: Strain localisation, faults, mylonites, neotectonics, Alpine Fault, New Zealand.

\section{Introduction}

Mylonite zones exposed in old rocks at the Earth's surface by uplift and erosion are generally considered to represent the deep portions of once active faults (e.g. Sibson, 1977; Hanmer, 1988). The rocks exhibit deformation by ductile creep processes under elevated conditions of pressure and temperature corresponding to depths of c. 10-30 $\mathrm{km}$. A model of a crustal fault zone consisting of an upper elastico-frictional part which ruptures periodically in earthquakes and a lower ductile portion in which strain accumulates by viscous creep is commonly adopted (e.g. Sibson, 1977, 1983; Hanmer, 1988). Localisation of creep strain within the underlying mylonite zone is therefore significant in localising elastic strain around the brittle seismogenic fault. A problem is that deep portions of currently active faults, for which surface structure, slip rate, seismic activity, etc., are known, are difficult to investigate or even image seismically (Stern and McBride, 1998). Ancient exposed mylonite zones, on the other hand, have usually lost the corresponding upper brittle portion.

In some cases, GPS measurements (e.g. Alpine Fault, Beavan et al., 1999) and satellite radar interferometry (e.g. North Anatolian Fault, Wright et al., 2001) indicate focussed strain around a locked surface fault, suggesting localised creep below some depth along a downward extension of the fault. In other cases, it has been argued that no

Copy right(c) The Society of Geomagnetism and Earth, Planetary and Space Sciences (SGEPSS); The Seismological Society of Japan; The Volcanological Society of Japan; The Geodetic Society of Japan; The Japanese Society for Planetary Sciences; TERRAPUB such localised creep occurs (e.g. Bourne et al., 1998). Important questions include: (1) How much of the slip on the brittle structure is accommodated by localised creep within a narrow mylonite zone beneath? (2) How do zones of high creep rate form below brittle faults and are they a precursor or a successor to localisation of displacement within the brittle crust? (3) Do all active faults have downward extensions of narrow creeping mylonite zones?

In this paper, I use geological and geophysical data from the Alpine Fault to argue for a deeply penetrating crustal mylonite zone beneath the surface fault, and draw a comparison with the behaviour of a suite of parallel faults in eastern South Island that lack evidence for deep creeping mylonite zones. I conclude from these data that a possible model for the development of mylonite zones is the downward propagation into the lower crust of a strain-weakened ductile shear zone localised by the reactivation of a preexisting upper crustal weakness.

\section{Alpine Fault, New Zealand}

\subsection{Regional setting and current activity}

The Alpine Fault is the main manifestation of the Australian-Pacific plate boundary within the South Island of New Zealand (Fig. 1; Norris et al., 1990). Estimates of Late Quaternary slip rates (Norris and Cooper, 2001) and contemporary strain accumulation measured by GPS surveys (Beavan et al., 1999) indicate that the Alpine Fault accommodates around two-thirds to three-quarters of the $37 \pm 2 \mathrm{~mm} / \mathrm{yr}$ of plate motion calculated from the Nuvel 1A global plate model (DeMets et al., 1994). The interplate 


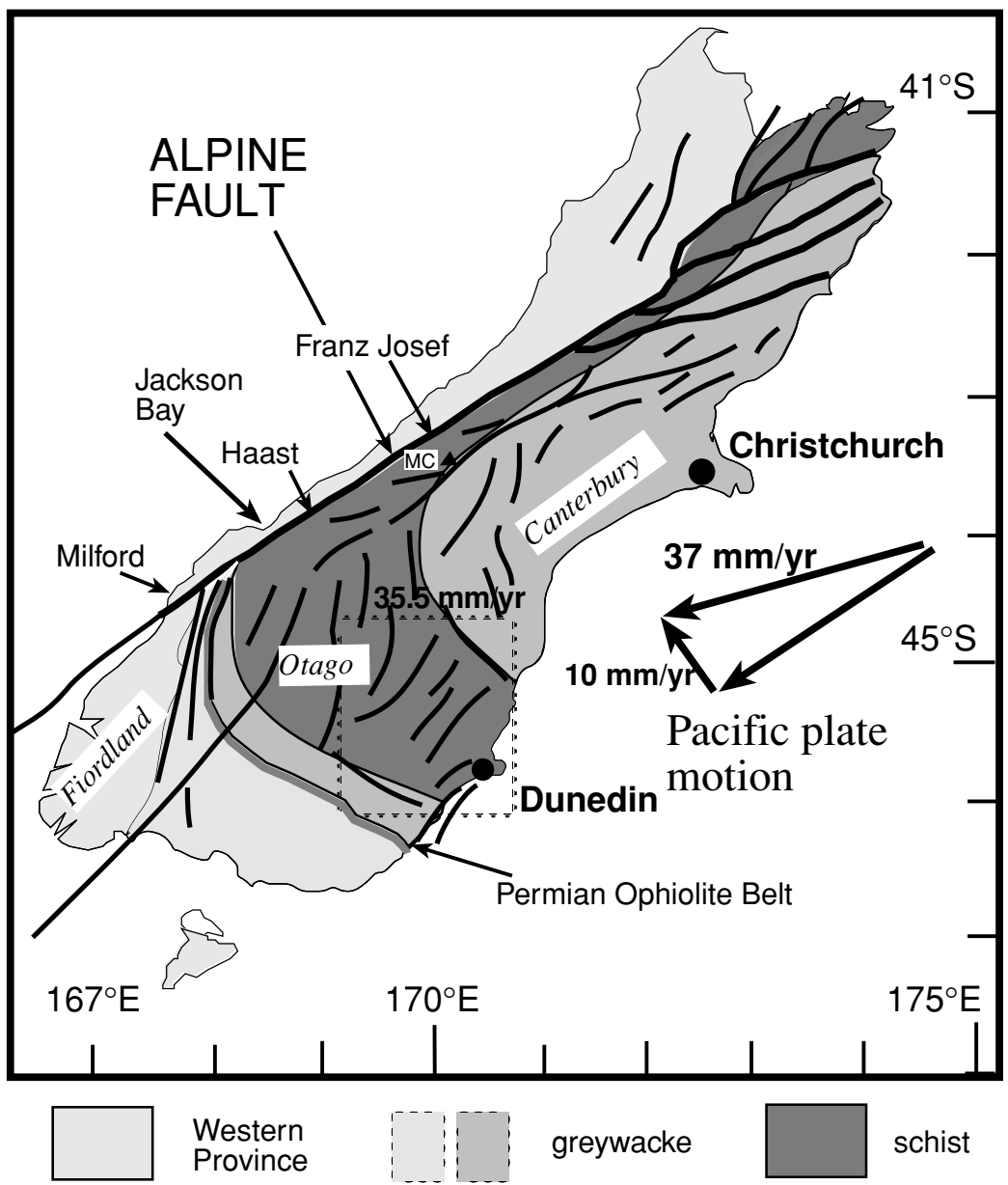

Fig. 1. Map of South Island showing Alpine Fault, distribution of major Late Quaternary faults (somewhat generalised) and current plate vector (after DeMets et al., 1994). Rectangle indicates area shown in Fig. 6.

slip vector is oriented approximately $20^{\circ}$ to the trace of the fault, resulting in components of $35.5 \mathrm{~mm} / \mathrm{yr}$ parallel and $10 \mathrm{~mm} / \mathrm{yr}$ perpendicular to the Alpine Fault. Motion on the fault within its central portion is approximately parallel to the interplate vector with components of both strike-slip and dip-slip. The dip-slip component reduces in the northeast and southwest of the South Island, and falls to zero on the far southwestern part of the fault south of Jackson Bay (Fig. 1; Norris and Cooper, 2001). Estimates of rates of strike-slip on the fault are consistent with a constant rate along its length of $27 \pm 6 \mathrm{~mm} / \mathrm{yr}$ (Norris and Cooper, 2001; revised estimates by Sutherland, Berryman and Norris (unpublished $\mathrm{ms}$ ) of $23.2 \pm 1.6 \mathrm{~mm} / \mathrm{yr}$ at the southern end of the fault may provide a more accurate rate). Reconstruction of plate motions through the late Cenozoic indicates a total convergence across the South Island of some 70-90 km (Walcott, 1998).

The depth to the Moho approximately doubles from c. $20 \mathrm{~km}$ off the east coast to $40 \mathrm{~km}$ under the Southern Alps (Davey et al., 1998; Van Avendonk et al., 2004). Part of the total convergence has been accommodated by crustal thickening forming a deep root. Walcott (1978) argued that geodetically measured strain is accommodated by ductile distributed creep within a broad zone across the South Island. The Late Quaternary slip data on the Alpine Fault (i.e. at least $23 \mathrm{~mm} / \mathrm{yr}$ ) indicate that this can only be true near surface for, at most, the remaining $14 \mathrm{~mm} / \mathrm{yr}$, or c. $35 \%$ of the predicted plate motion. Based on mantle anisotropy, Molnar et al. (1999) and Stern et al. (2000) have suggested that New Zealand overlies a broad zone of shear some 200 $\mathrm{km}$ wide and localisation onto faults only occurs in the brittle crust.

On a short CDP reflection line east of the Alpine Fault, Davey et al. (1995) recognised reflections dipping at 40$50^{\circ}$ in line with the surface trace of the Alpine Fault and extending to a depth of over $25 \mathrm{~km}$. These were interpreted as the extension of the Alpine Fault zone into the lower crust.

Rocks from over $20 \mathrm{~km}$ depth have been exhumed within the last few million years within the hangingwall due to the component of convergence across the Alpine Fault (Cooper, 1980; Adams, 1981; Holm et al., 1989). East of the surface trace, a zone up to $1 \mathrm{~km}$ wide of mylonite and protomylonite is exposed (Reed, 1964; Sibson et al., 1979; Norris and Cooper, 2003). Mylonitisation increases inhomogeneously westwards across the zone from amphibolite facies schist protolith in the east, to protomylonite, mylonite, and ultramylonite adjacent to the active fault trace. Mineral assemblages in the mylonites indicate deformation under amphibolite facies conditions at depths of 20-30 km (Holm et al., 1989; Grapes and Watanabe, 1994; Vry et al., 2004). We can definitely say that a narrow zone of faulting with a slip 

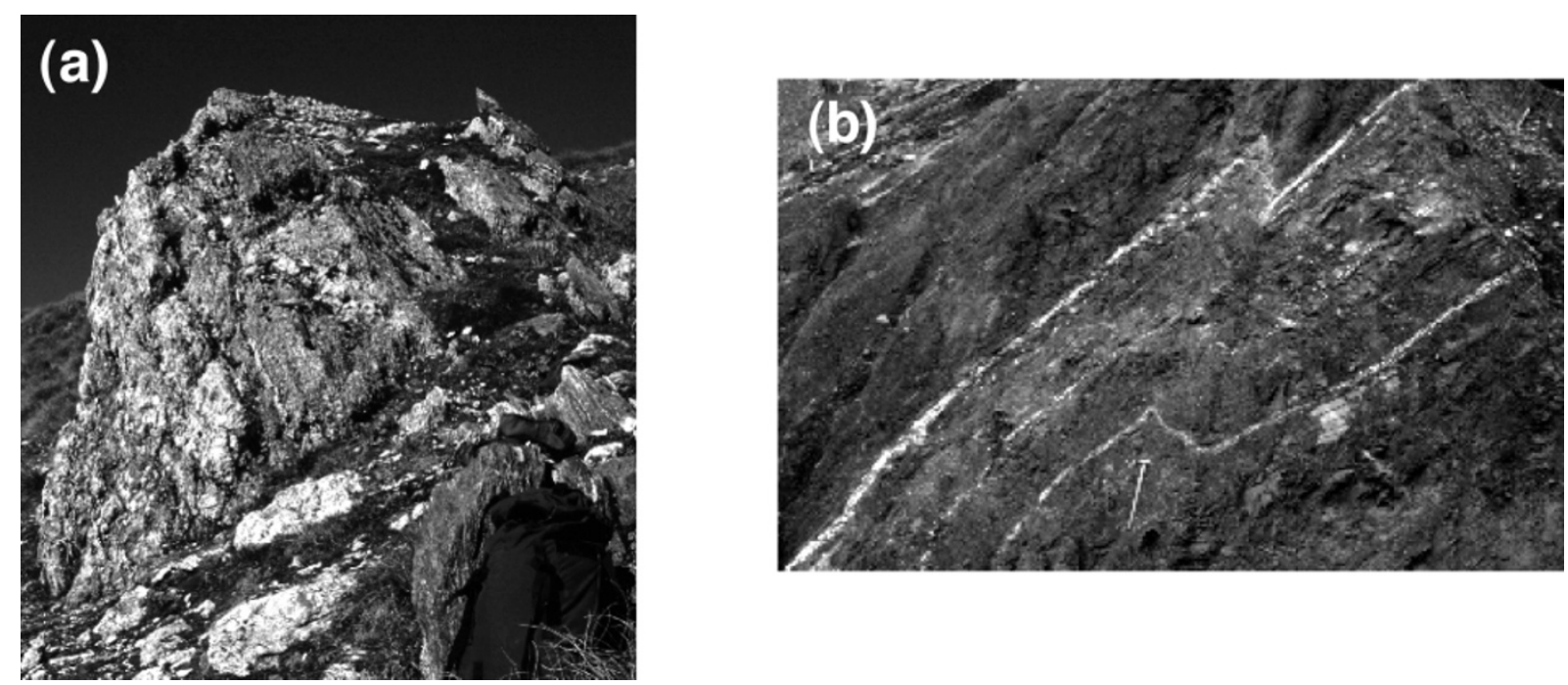

Fig. 2. (a) Non-mylonitised pegmatite in hangingwall schist near Haast; (b) highly attenuated pegmatite veins in ultramylonites near Franz Josef.

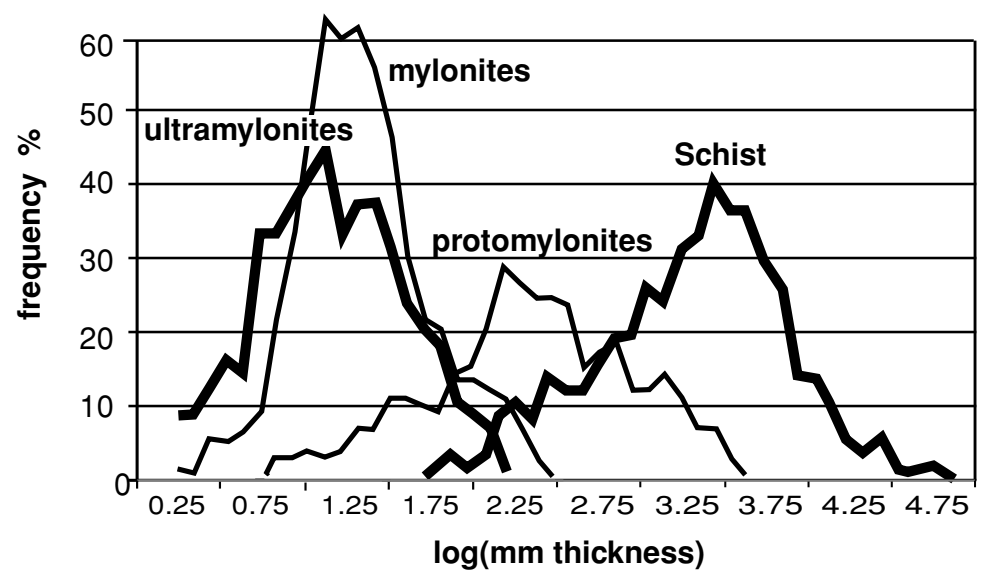

Fig. 3. Plot of smoothed frequency distributions of thickness of pegmatite veins in different parts of the mylonite zone (after Norris and Cooper, 2003).

rate of around $25 \mathrm{~mm} / \mathrm{yr}$ at the surface overlies a mylonite zone 1-2 km wide originally developed at a depth of 20-30 $\mathrm{km}$. The Alpine Fault, therefore, presents a rare opportunity to study the deep-seated part of a currently active fault whose surface dimensions and structure we already know and whose slip rate and slip direction we can determine.

\subsection{Alpine Fault mylonite zone}

Strain within the mylonites, as indicated by the intensity of development of a mylonitic foliation and degree of grainsize reduction, increases towards the present surface trace of the Alpine Fault. Large strains in the more deformed mylonites are indicated by the parallelism of all features with the foliation and the destruction of most of the original schist fabric. Shear sense indicators on both mesoscopic and microscopic scales consistently record oblique dextralreverse shear in accordance with the recent slip on the fault (Prior, 1988; Little et al., 2002). A strong convergent component developed on the fault around 5-6 Ma (Sutherland, 1995), since when there has been at least $70 \mathrm{~km}$ of convergence across the whole plate boundary (Walcott, 1998). It is likely, therefore, that the mylonites currently exposed formed within this period of convergence.

Norris and Cooper (2003) addressed the question of what proportion of the surface fault displacement can be accommodated by ductile creep within the mylonites. They measured the thicknesses of pegmatite veins within a $65 \mathrm{Ma}$ swarm that is progressively sheared across the mylonite zone and compared the thickness distributions of the deformed veins with that of their un-mylonitised counterparts to calculate a finite shear strain within different parts of the mylonites (Figs. 2, 3). Depending on assumptions, shear strains ranged from 12-22 in the protomylonites, 120-200 in the main mylonites and 180-300 in the ultramylonites. By fitting an exponential function to these strains across the exposed zone, an integrated displacement of 55-60 km may be calculated (Norris and Cooper, 2003; Fig. 4). This is also consistent with the pegmatites extending through the mylonite zone over a distance of at least $60 \mathrm{~km}$ parallel to strike.

In $5 \mathrm{Ma}$ at an average slip rate of $25 \mathrm{~mm} / \mathrm{yr}$, some 125 $\mathrm{km}$ of displacement is predicted. Earthquakes in the vicinity of the Alpine Fault are restricted to the top $10 \mathrm{~km}$ of crust (Leitner et al., 2001), indicating that the ductile strains accumulated below this depth-i.e. between 30 and $10 \mathrm{~km}$ depth, The strain recorded in the mylonites, therefore, would represent only two-thirds of the total surface 


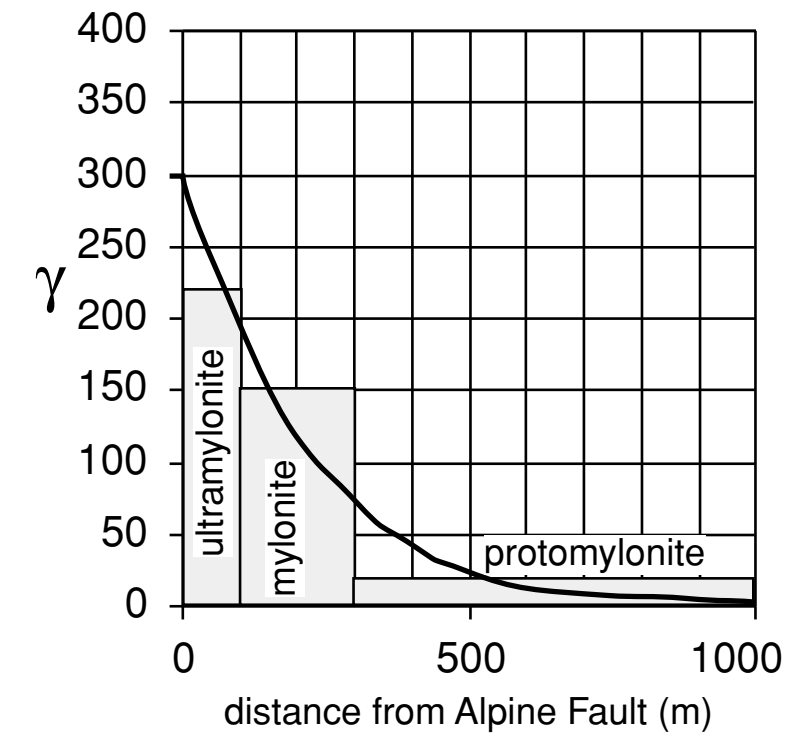

Fig. 4. Strain profile across the mylonite zone. Boxes are estimated strains for the three subzones. The smooth curve is an exponential fit (after Norris and Cooper, 2003).

slip accumulated during their uplift-i.e. c. $85 \mathrm{~km}$. The highest strained mylonites are immediately adjacent to the present brittle fault, suggesting that a portion of the mylonite zone lies at depth within the footwall. If the original ductile zone were symmetric, it would have been twice the width of the exposed zone, although a highly asymmetric zone is also possible. Therefore total displacement across the mylonite zone would lie between 60 and $120 \mathrm{~km}$ (Norris and Cooper, 2003). This value is compatible with all the required displacement on the fault being accommodated by ductile shear within a $1-2 \mathrm{~km}$ wide mylonite zone within the lower crust.

\subsection{Displacement rate and seismic behaviour of the} Alpine Fault

Estimates of Late Quaternary (last $50 \mathrm{ka}$ ) rates of slip on the Alpine Fault of $27 \pm 6 \mathrm{~mm} / \mathrm{yr}$ (Norris and Cooper, 2001) are consistent with the long-term estimate of Sutherland (1994) of $26 \mathrm{~mm} / \mathrm{yr}$ since the mid Pliocene. We can conclude from these results that the rate of strike-slip displacement on the fault has been reasonably constant over a long period of time.

Results of repeated GPS surveys across the South Island (Beavan et al., 1999) show high strains accumulating within a zone about $30 \mathrm{~km}$ wide east of the Alpine Fault. Velocities relative to the Pacific plate show a rapid decrease eastwards within $15 \mathrm{~km}$ of the surface trace. In order to explain these observations, Beavan et al. (1999) use various dislocation models. A combination of localised ductile shear on an eastward dipping extension of the Alpine Fault below $8 \mathrm{~km}$ locking depth combined with slip on a deeper, westward dipping structure (or a more distributed deformation) best fit the data. The data require around $60 \%$ of interplate slip to be concentrated as ductile creep within an extension to the Alpine Fault below c. $8 \mathrm{~km}$ and extending to at least $15 \mathrm{~km}$ and probably $30 \mathrm{~km}$ depth. The balance may be distributed on a number of possible structures, including a broader thickening of the crust. Above $8 \mathrm{~km}$, strain is

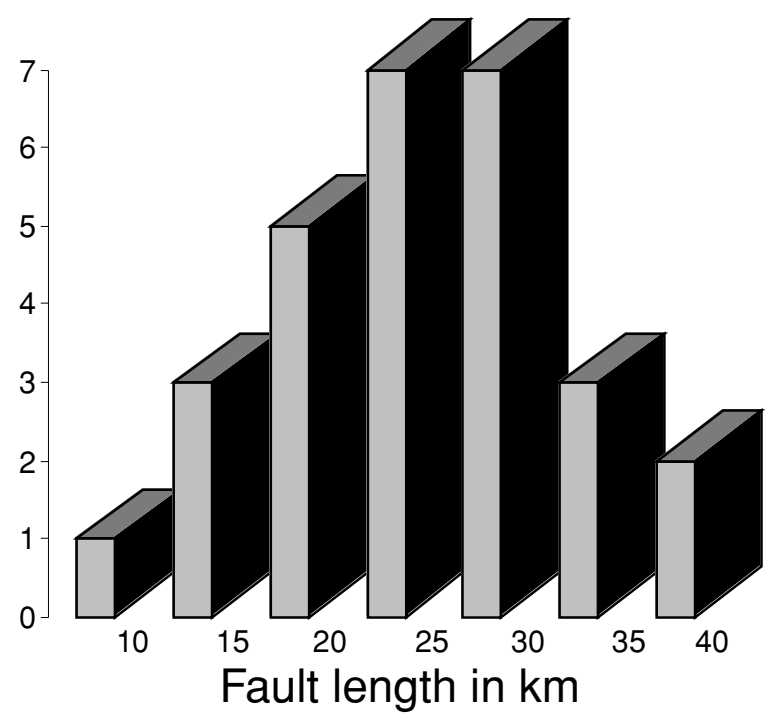

mean: $24 \mathrm{~km}$ std dev.: $7 \mathrm{~km}$

Fig. 5. Histograms of lengths of Late Quaternary fault traces east of the Alpine Fault.

considered elastic and no evidence for aseismic creep on the fault is present. Thus the geodetic data is consistent with the structural results in supporting a creeping mid-lower crustal extension of the fault.

There have been no ground ruptures on the Alpine Fault since written records began in the early 19th century. Paleoseismic studies, however, have provided evidence of substantial surface breaks along large sections of the fault (Cooper and Norris, 1990; Sutherland and Norris, 1995; Bull, 1996; Yetton et al., 1998; Wells et al., 1999; Norris et al., 2001; Rhoades and van Dissen, 2003) every 200 350 years since $900 \mathrm{AD}$. The last surface break is dated by dendrochronology as occurring in $1717 \mathrm{AD}$ (Wells et al., 1999) and probably broke most of the $400 \mathrm{~km}$ surface trace. Single displacements range from 5 to $8 \mathrm{~m}$ dextral. Vertical offsets range from 0 to $2 \mathrm{~m}$ although no single offset data are available in the central part of the fault where the longterm average rate of vertical offset is greatest. At $25 \mathrm{~mm} / \mathrm{yr}$, $5 \mathrm{~m}-8 \mathrm{~m}$ breaks would be expected every $200-320$ yrs, so that the paleoseismic record and the long-term average slip rates are in general agreement.

All the above data indicate a fault that shows a more or less constant long-term average slip rate and a cyclical build-up and release of elastic strain in the seismogenic crust. Coupled with the geodetic data, this behaviour is compatible with a fault in which localised creep within a deep extension to the brittle fault is occurring at a more or less constant rate and is partly instrumental in focussing the build-up of elastic strain around the surface trace.

\section{Otago Fault System}

\subsection{Faulting east of the Southern Alps}

As noted above, only around $60-70 \%$ of the total interplate displacement is accommodated by slip on the Alpine Fault. The lack of much micro-seismic activity west of the fault (Leitner et al., 2001) suggests the rest is distributed mainly to the east on a number of smaller faults and folds 


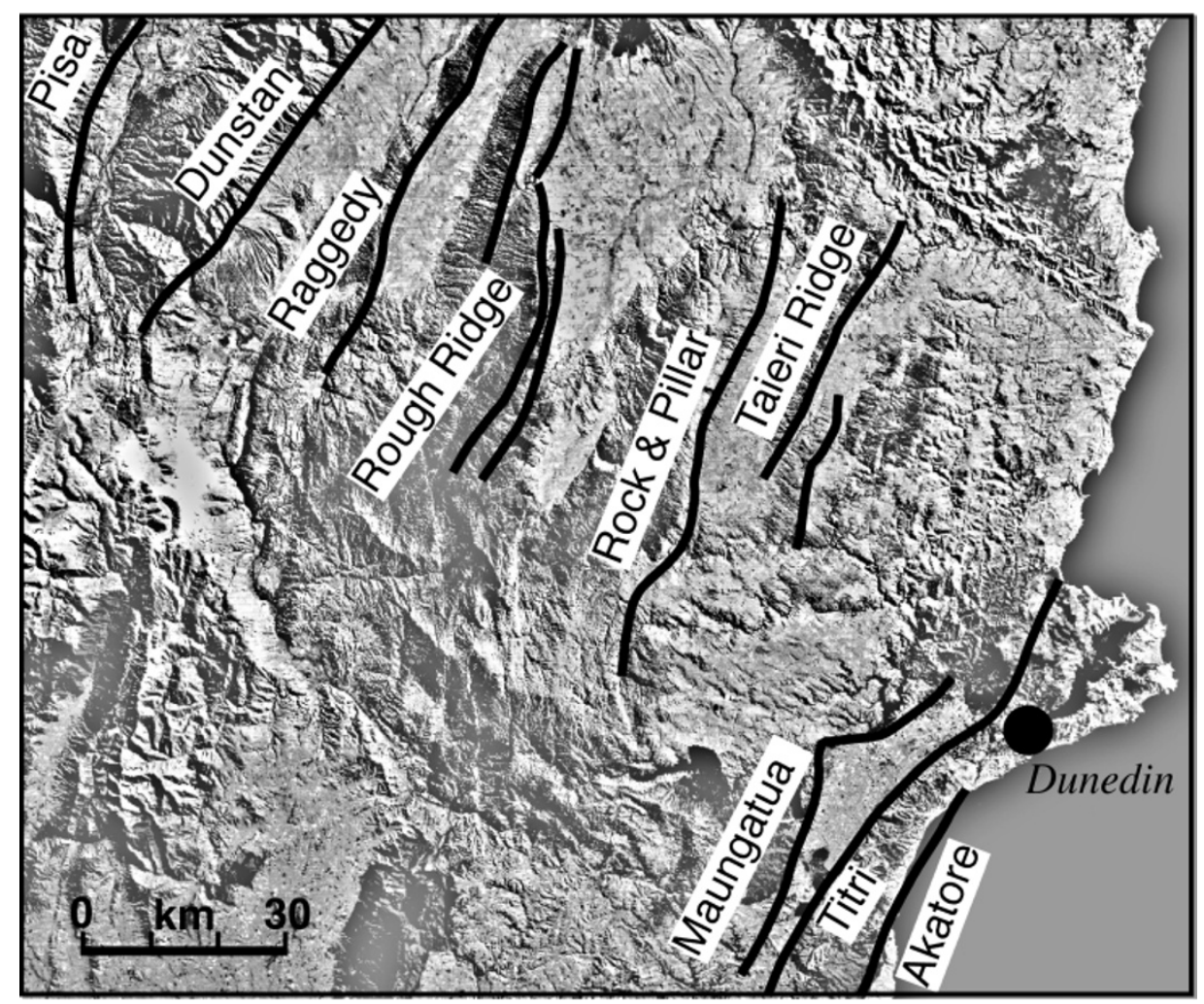

Fig. 6. Relief image of Otago (processed from Landsat images) showing NE-striking Late Quaternary faults and uplifted anticlinal ranges (note: only NE-striking faults referred to in text are shown; Cardrona Fault is just off the image to the NW; the Alpine Fault is not shown). Area of view is shown by box in Fig. 1.

(Norris and Cooper, 2001). Figure 5 is a histogram showing the lengths of Quaternary surface traces of faults east of the Alpine Fault, taken from regional maps (e.g. Officers of the Geological Survey, 1983). The average fault length is $24 \mathrm{~km}$ and typical surface displacements measured for a single event are 1-2 m. About 12 faults of this length would be needed to stretch the $300 \mathrm{~km}$ or so of the central Alpine Fault. If about $10 \mathrm{~mm} / \mathrm{yr}$ of plate movement is being accommodated east of the Alpine Fault, we might expect around 12 faults of this size to rupture every 100-200 years, with earthquakes of around M6.5-7 (Wells and Coppersmith, 1994).

\subsection{Otago fault system}

In Otago, a series of NE-striking ranges extend across the province from the Southern Alps to the coast (Fig. 6). Mainly west-dipping reverse faults bound the ranges. These faults are predominantly blind thrust faults, with subdued surface expression, and border anticlinally folded ranges (Jackson et al., 1996; Markley and Norris, 1999). Several of the faults are complex, with frontal splays and offset segments (Jackson et al., 1996). Total vertical displacement across the ten faulted ranges may be estimated from the offset of a Cretaceous-early Tertiary erosion surface (Bishop, 1994; LeMasurier and Landis, 1996). Vertical displacements on individual structures range from c. $2000 \mathrm{~m}$ to 120 $\mathrm{m}$, with an average of about $1000 \mathrm{~m}$. Stratigraphic evidence indicates uplift of the ranges occurred during the Quaternary (Youngson et al., 1998). By adding estimates of total displacements on all major structures, an average uplift rate across the whole system of $2-3 \mathrm{~mm} / \mathrm{yr}$ is obtained. If the faults are assumed to dip at $45^{\circ}$, this is also equal to the average shortening rate across the province. This value is in reasonable agreement with preliminary GPS data (Norris and Nicolls, 2004), suggesting that rates of shortening across the whole system may be fairly constant.

Typical single displacements on the range fronts range from $1-3 \mathrm{~m}$. If all 10 faults were moving at the same constant rate of $0.2 \mathrm{~mm} / \mathrm{yr}$, each would have a return period of 5-15 ka. Limited paleoseismic data on the Dunstan Fault (Beanland et al., 1986) is compatible with this whereas recent movement on the Akatore Fault (Litchfield and Norris, 2000) is faster. What is remarkable is that all four faults investigated paleoseismically (Pisa Fault, Beanland and Berryman, 1989; Dunstan Fault, Beanland et al., 1986; Titri Fault, Litchfield, 2001; Akatore Fault, Litchfield and Norris, 2000) show periods of quiescence of more than $100 \mathrm{ka}$, i.e. 10 times the average return period. This led Beanland and Berryman (1989) to suggest that movement on each fault was episodic, and switched between one fault and another (termed "intermittently characteristic" behaviour by Beanland and Berryman, 1989). Similar behaviour has been suggested for other systems of parallel faults (Wallace, 1987; Jackson and Leeder, 1994).

Such behaviour as outlined above indicates that the faults cannot have a constant rate of slip, nor do they produce ruptures at regular intervals. Each fault may be active for a period and then become quiescent while movement transfers to another structure. Such behaviour is more typical of faults within an elastic upper crust overlying a uniformly weak lower crust within which stress relaxation occurs by 
distributed creep (e.g. Ellis et al., 2004; also see Ben-Zion et al., 1999), rather than each fault having an individual creeping downward continuation into the lower crust.

\section{Discussion}

Geodetic data, geologic slip-rate data, and paleoseismic information are all consistent with the Alpine Fault within the seismogenic crust overlying a downward extension into the lower crust in which ductile creep strain is localised. This is compatible with the evidence from the exhumed mylonite zone alongside the present fault trace, that shows very large shear strains and intense strain localisation. Information on the Otago fault system on the other hand, while preliminary, is consistent with a set of faults within an elasticofrictional upper crust overlying a ductile lower crust and lacking zones of strongly localised creep beneath each fault.

Major differences between these fault systems are that the rate of slip on the Alpine Fault is much higher than on the Otago Faults, and its strike length is over an order of magnitude greater. Both fault systems appear to represent, at least in part, reactivated older structures within the crust (e.g. Sutherland et al., 2000; Turnbull et al., 1993). Molnar et al. (1999) have argued from seismic data that the mantle beneath the South Island is deforming by distributed shear without a zone of highly localised creep. If this is accepted, the localisation of deformation on the Alpine Fault is unlikely to derive directly from the mantle. Maggi et al. (2000) and Jackson (2002) have recently questioned the assumption of high strength upper mantle and have suggested that most of the continental lithospheric strength lies in the seismogenic crust. In this scenario, weak zones within the upper crust may localise brittle deformation along major faults, which in turn will cause cyclical high stresses and high strain-rates in the lower crust immediately below them (White, 1996; Ellis and Stöckhert, 2004). If strain weakening occurs due to the increase in strain (cf. Hobbs et al., 2002), a zone of enhanced ductile creep will propagate downwards from the upper crustal fault and a positive feedback loop will lead eventually to a highly focussed fault zone through the crust. Associated with this, pronounced exhumation during localised uplift on the fault will also result in focussed thermal weakening (Ellis et al., 2001; Koons et al., 2003)

In the early history of the plate boundary, deformation was distributed across a broad region rather than focussed on the Alpine fault (Sutherland, 1999). The discontinuity that localised the Alpine Fault was the old passive margin along the Resolution Ridge (Sutherland et al., 2000). This was a long linear feature, and so the localisation of deformation was pronounced. The Otago faults are reactivated from a set of Cretaceous normal faults and are too short to accumulate large amounts of displacement. Slip on individual structures is as yet too small to have generated deep zones of ductile creep beneath each one.

Long fault zones focus more deformation and high slip rates generate a strain-weakened ductile shear zone below that feeds back positively in localising deformation. Short multiple discontinuities have too low slip rates to develop deep zones of strain-weakened mylonites.
Acknowledgments. I thank Alan Cooper, John Youngson, Kelvin Berryman, Peter Koons, James Jackson and Paul Denys who collaborated on much of the research into NZ faults, Rick Sibson for discussion, James Jackson for reading an early draft, and the Journal referees Takeshi Sagiya and Tim Little for valuable suggestions. Research was supported by the Public Good Science Fund of New Zealand, EQC Research Foundation and Otago University.

\section{References}

Adams, C. J., Uplift rates and thermal structure in the Alpine Fault Zone and Alpine Schists, Southern Alps, New Zealand, in Thrust and Nappe Tectonics, edited by K. McClay and N. J. Price, pp. 211-222, Geological Society of London Special Publication, 9, 1981.

Beanland, S. and K. R. Berryman, Style and episodicity of late Quaternary activity on the Pisa-Grandview fault zone, central Otago, New Zealand, New Zealand Journal of Geology and Geophysics, 32, 451-461, 1989.

Beanland, S., K. R. Berryman, A. G. Hull, and P. R. Wood, Late Quaternary deformation at the Dunstan Fault, Central Otago, New Zealand, in Recent Crustal Movements of the Pacific Region, edited by W. I. Reilly and B. E. Harford, pp. 293-306, Royal Society of New Zealand Bulletin, 24, 1986.

Beavan, J., M. Moore, C. Pearson, M. Henderson, B. Parsons, S. Bourne, P. England, D. Walcott, G. Blick, D. Darby, and K. Hodgkinson, Crustal deformation during 1994-1998 due to oblique continental collision in the central Southern Alps, New Zealand, and implications for seismic potential of the Alpine fault, Journal of Geophysical Research, 104, 25,232-25,255, 1999.

Ben-Zion, Y., K. Dahman, V. Lyakhovsky, D. Ertas, and A. Agnon, Selfdriven mode switching of earthquake activity on a fault system, Earth and Planetary Science Letters, 172, 11-21, 1999.

Bishop, D. G., Extent and regional deformation of the Otago peneplain, Institute of Geological and Nuclear Sciences Science Report, 94/1, 10 pp., 1994.

Bourne, S. J., T. Arnadottir, J. Beavan, D. J. Darby, P. C. England, B. Parsons, R. I. Walcott, and P. R. Wood, Crustal deformation of the Marlborough fault zone in the South Island of New Zealand: Geodetic constraints over the interval 1982-1994, Journal of Geophysical Research, 103, 30147-30165, 1998.

Bull, W. B., Prehistorical earthquakes on the Alpine Fault, New Zealand, Journal of Geophysical Research, 101, 6037-6050, 1996.

Cooper, A. F., Retrograde alteration of chromium kyanite in metachert and amphibolite whiteschist from the Southern Alps, New Zealand, with implications for uplift on the Alpine Fault, Contributions to Mineralogy \& Petrology, 75, 153-164, 1980.

Cooper, A. F. and R. J. Norris, Estimates for the timing of the last coseismic displacement on the Alpine fault, northern Fiordland, New Zealand, New Zealand Journal of Geology and Geophysics, 33, 303-308, 1990.

Davey, F. J., T. Henyey, W. S. Holbrook, D. Okaya, T. A. Stern, A. Melhuish, S. Henrys, H. Anderson, D. Eberhart-Phillips, T. McEvilly, R. Uhrhammer, F. Wu, G. R. Jiracek, P. E. Wannamaker, G. Caldwell, and N. Christensen, Preliminary results from a geophysical study across a modern continent-continent collisional plate boundary-the Southern Alps, New Zealand, Tectonophysics 288, 221-235, 1998.

Davey, F. J., T. Henyey, S. Kleffmann, A. Melhuish, D. Okaya, T. A. Stern, and D. J. Woodward, Crustal reflections from the Alpine Fault zone, South Island, New Zealand, New Zealand Journal of Geology and Geophysics, 38, 601-604, 1995.

DeMets, C., R. G. Gordon, D. F. Argus, and S. Stein, Effect of recent revisions to the geomagnetic reversal time scale on estimates of current plate motions, Geophysical Research Letters, 21, 2191-2194, 1994.

Ellis, S. and B. Stöckhert, Elevated stresses and creep rates beneath the brittle-ductile transition caused by seismic faulting in the upper crust, Journal of Geophysical Research, 109(B5), Article no. B05407, 2004.

Ellis, S., S. Wissing, and A. Pfiffner, Strain localisation as a key to reconciling experimentally derived flow-law data with dynamic models of continental collision, International Journal of Earth Sciences, 90, 168180, 2001.

Ellis, S., G. Schreurs, and M. Panien, Comparisons between analogue and numerical models of thrust wedge development, Journal of Structural Geology, 26, 1659-1675, 2004.

Grapes, R. H. and T. Watanabe, Mineral composition variation in Alpine Schist, Southern Alps, New Zealand: Implications for recrystallization and exhumation, The Island Arc, 3, 163-181, 1994.

Hanmer, S., Great Slave Lake Shear Zone, Canadian Shield: A reconstructed vertical profile of a crustal scale fault, Tectonophysics, 149, 
245-264, 1988.

Hobbs, B. E., H. Tanaka, and Y. Iio, Acceleration of slip motion in deep extensions of seismogenic faults in and below the seismogenic region, Earth Planets Space, 54, 1195-1205, 2002.

Holm, D. K., R. J. Norris, and D. Craw, Brittle/ductile deformation in a zone of rapid uplift: Central Southern Alps, New Zealand, Tectonics, 8 , 153-168, 1989.

Jackson, J. and M. Leeder, Drainage systems and the development of normal faults: An example from Pleasant Valley, Nevada, Journal of Structural Geology, 16, 1041-1060, 1994.

Jackson, J. A., Strength of the continental lithosphere: Time to abandon the jelly sandwich?, GSA Today, 12, 4-10, 2002.

Jackson, J. A., R. J. Norris, and J. H. Youngson, The structural evolution of active fault and fold systems in central Otago, New Zealand: Evidence revealed by drainage patterns, Journal of Structural Geology, 18, $217-$ 235, 1996.

Koons, P. O., R. J. Norris, D. Craw, and A. F. Cooper, Influence of exhumation on the structural evolution of transpressional plate boundaries: An example from the Southern Alps, New Zealand, Geology, 31, 3-6, 2003.

Leitner, B. D., D. Eberhart-Philips, H. Anderson, and J. N. Nabelek, A focused look at the Alpine Fault, New Zealand: Seismicity, focal mechanisms and stress inversions, Journal of Geophysical Research, 106, 2193-2220, 2001.

LeMasurier, W. E. and C. A. Landis, Mantle-plume activity recorded by low-relief erosion surfaces in West Antarctica and New Zealand, Geological Society of America Bulletin, 108, 1450-1466, 1996.

Litchfield, N. J., The Titri Fault system: Quaternary-active faults near the leading edge of the Otago reverse fault province, New Zealand Journal of Geology and Geophysics, 44, 517-534, 2001.

Litchfield, N. J. and R. J. Norris, Holocene motion on the Akatore Fault, south Otago coast, New Zealand, New Zealand Journal of Geology and Geophysics, 43, 405-418, 2000.

Little, T. A., R. J. Holcombe, and B. R. Ilg, Kinematics of oblique collision and ramping inferred from microstructures and strain in middle crustal rocks, central Southern Alps, New Zealand, Journal of Structural Geology, 24, 219-239, 2002.

Maggi, A., J. Jackson, D. McKenzie, and K. Priestley, Earthquake focal depths, effective elastic thickness, and the strength of the continental lithosphere, Geology, 28, 495-498, 2000.

Markley, M. and R. J. Norris, Structure and Neotectonics of the Blackstone Hill Antiform, central Otago, New Zealand, New Zealand Journal of Geology \& Geophysics, 42, 205-218, 1999.

Molnar, P., H. J. Anderson, E. Audoine, D. Eberhart-Phillips, K. R. Gledhill, E. K. Klosko, T. V. McEvilly, D. Okaya, M. K. Savage, T. Stern, and F. T. Wu, Continuous deformation versus faulting through continental lithosphere: Tests using New Zealand as a laboratory for the study of continental dynamics, Science, 286, 516-519, 1999.

Norris, R. J. and A. F. Cooper, Late Quaternary slip rates and slip partitioning on the Alpine Fault, New Zealand, Journal of Structural Geology, 23, 507-520, 2001

Norris, R. J. and A. F. Cooper, Very high strains recorded in mylonites along the Alpine Fault, New Zealand: Implications for the deep structure of plate boundary faults, Journal of Structural Geology, 25, 2141-2157, 2003.

Norris, R. J. and R. Nicolls, Strain accumulation and episodicity of fault movements in Otago, 145 pp, EQC Research Report, 01/445, EQC Research Foundation, Wellington, 2004.

Norris, R. J., A. F. Cooper, T. Wright, and K. R. Berryman, Dating of past Alpine Fault rupture in South Westland, 75 pp, EQC Research Report, 99/341, EQC Research Foundation, Wellington, 2001.

Norris, R. J., P. O. Koons, and A. F. Cooper, The obliquely-convergent plate boundary in the South Island of New Zealand: Implications for ancient collision zones, Journal of Structural Geology, 12, 715-725, 1990.

Officers of the Geological Survey, Late Quaternary Tectonic Map of New Zealand 1:2 000 000, New Zealand Geological Survey Miscellaneous Series, Map 12, Department of Scientific and Industrial Research, Wellington, 1983.

Prior, D. J., Deformation processes in the Alpine Fault mylonites, South Island, New Zealand, unpublished $\mathrm{PhD}$ thesis, University of Leeds, U. K., 1988.

Reed, J. J., Mylonites, cataclasites, and associated rocks along the Alpine Fault, South Island, New Zealand, New Zealand Journal of Geology and Geophysics, 7, 645-684, 1964.

Rhoades, D. A. and R. J. van Dissen, Estimates of the time-varying hazard of rupture of the Alpine Fault, New Zealand, allowing for uncertainties, New Zealand Journal of Geology and Geophysics, 46, 479-488, 2003.

Sibson, R. H., Fault rocks and fault mechanisms, Geological Society of London Journal, 133, 191-213, 1977.

Sibson, R. H., Continental fault structure and the shallow earthquake source, Geological Society of London Journal, 140, 741-767, 1983.

Sibson, R. H., S. H. White, and B. K. Atkinson, Fault rock distribution and structure within the Alpine Fault Zone: A preliminary account, in The Origin of the Southern Alps, edited by R. I. Walcott and M. M. Cresswell, pp. 55-65, Bulletin of the Royal Society of New Zealand, $18,1979$.

Stern, T. A. and J. H. McBride, Seismic exploration of continental strikeslip zones, Tectonophysics, 286, 63-78, 1998.

Stern, T., P. Molnar, D. Okaya, and D. Eberhart-Phillips, Teleseismic Pwave delays and modes of shortening the mantle lithosphere beneath South Island, New Zealand, Journal of Geophysical Research, 105, 21,615-21,631, 2000.

Sutherland, R., Displacement since the Pliocene along the southern section of the Alpine fault, New Zealand, Geology, 22, 327-331, 1994.

Sutherland, R., The Australia-Pacific boundary and Cenozoic plate motions in the southwest Pacific: Some constraints from Geosat data, Tectonics, 14, 819-831, 1995.

Sutherland, R., Cenozoic bending of New Zealand basement terranes and Alpine Fault displacement: A brief review, New Zealand Journal of Geology and Geophysics, 42, 295-301, 1999.

Sutherland, R. and R. J. Norris, Late Quaternary displacement rate, paleoseismicity, and geomorphic evolution of the Alpine Fault: Evidence from Hokuri Creek, South Westland, New Zealand, New Zealand Journal of Geology and Geophysics, 38, 419-430, 1995.

Sutherland, R., F. Davey, and J. Beavan, Plate boundary deformation in South Island, New Zealand, is related to inherited lithospheric structure, Earth and Planetary Science Letters, 177, 141-151, 2000.

Turnbull, I. M., D. Craw, and R. J. Norris, Pre-Miocene and post-Miocene faulting in the Bannockburn Basin, central Otago, New Zealand, New Zealand Journal of Geology and Geophysics, 36, 107-115, 1993.

Van Avendonk, H. J. A., W. S. Holbrook, D. Okaya, J. K. Austin, F. Davey, and T. Stern, Continental crust under compression: A seismic refraction study of South Island Geophysical Transect I, South Island, New Zealand, Journal of Geophysical Research, 109(B6), B06302, 2004.

Vry, J. K., R. Maas, T. A. Little, D. Phillips, R. Grapes, and M. Dixon, Zoned (Cretaceous and Cenozoic) garnets and the timing of high-grade metamorphism, Southern Alps, New Zealand, Journal of Metamorphic Geology, 22, 137-157, 2004.

Walcott, R. I., Modes of oblique compression: Late Cenozoic tectonics of the South Island, New Zealand, Reviews of Geophysics, 36, 1-26, 1998.

Walcott, R. I., Present tectonics and late Cenozoic evolution of New Zealand, Geophysical Journal of the Royal Astronomical Society, 52, 137-164, 1978.

Wallace, R. E., Grouping and migration of surface faulting and variations in slip rates on faults in the Great Basin Province, Seismological Society of America Bulletin, 77, 868-876, 1987.

Wells, D. L. and K. J. Coppersmith, New empirical relationships among magnitude, rupture length, rupture width, rupture area, and surface displacement, Seismological Society of America Bulletin, 84, 974-1002, 1994.

Wells, A., M. D. Yetton, R. P. Duncan, and G. H. Stewart, Prehistoric dates of the most recent Alpine fault earthquakes, New Zealand, Geology, 27, 995-998, 1999.

White, J. C., Transient discontinuities revisited: Pseudotachylytes, plastic instability and the influence of low pore fluid pressure on deformation processes in the mid-crust, Journal of Structural Geology, 18, 14711486, 1996.

Wright, T., B. Parsons, and E. Fielding, Measurement of interseismic strain accumulation across the North Anatolian Fault by satellite radar interferometry, Geophysical Research Letters, 28, 2117-2120, 2001.

Yetton, M. D., A. Wells, and N. J. Traylen, The probabilities and consequences of the next Alpine Fault earthquake, EQC Research Report 95/193, EQC Research Foundation, Wellington, 1998.

Youngson, J. H., D. Craw, C. A. Landis, and K. R. Schmitt, Redefinition and interpretation of late Miocene-Pleistocene terrestrial stratigraphy, Central Otago, New Zealand, New Zealand Journal of Geology and Geophysics, 41, 51-68, 1998.

R. J. Norris (e-mail: richard.norris@stonebow.otago.ac.nz) 